\title{
IPMN に対する外科治療指針の現況
}

\author{
木村理 森谷 敏幸 渡邊 利広 \\ 神尾 幸則平井一郎*
}

\begin{abstract}
要 旨：IPMN の病態についてはさまざまな未解決の問題点がある. 臨床的には, 浸潤はど の程度になったら画像診断その他でとらえられるか. 浸潤し始めてからも slow growing か, 浸潤が明らかになってからの手術で間に合うか, さまざまな進展度の病変に対して, どのような手術がもっとも優れているか, どのような縮小手術が可能か，などである，こ れは IPMN 由来浸潤癌が通常型膵癌と比較してどの程度悪性か, という問題でもある.

われわれの経験では, IPMN 切除症例 60 例のうち 14 例が IPMN 由来浸潤癌で, その 5 年生存率は Kaplan-Meier 法で約 40\%であった. IPMN が浸潤し始めてからも臨床的に slow growing であることを示唆する所見であるが, IPMN 非浸潤癌症例の 5 年生存率 $100 \%$ に比較すればけっして満足すべき数字ではない.したがって, これまで思われていた より悪性の疾患であることを考慮して治療にあたるべきである。ささざまな縮小手術が試 みられているが、縮小手術をしたことによって宿主 (患者)を再発死させてはならない」と いう腫瘍外科手術の大前提を念頭に置きながら，機能温存によっていかなる恩恵を受けた かを客観的に示していくことが重要である．機能温存手術の適応は厳密にすべきである.
\end{abstract}

索引用語：IPMN 縮小手術 十二指晹温存膵頭切除術 脾温存膵体尾部切除術

はじめに

膵管内乳頭粘液性腫瘍 (IPMN) は臨床の場で高 頻度に発見されるようになり, 膵疾患の中で重要 な位置を占めている. IPMN の概念は大橋ら ${ }^{1}$ が 1982 年に提唱した「粘液産生膵腫瘍」を病理学的 見地からとらえたもので, 最近ではIPMN/MCN の国際ガイドライン゙2が作成され, 国際的なコンセ ンサスが得られている.

IPMN は当初「予後の良い膵癌」と報告され，そ の疾患概念や手術適応をめぐってさまざまな議論 がなされてきた．また手術術式についても，従来 の膵頭十二指晹切除術から膵の機能温存手術まで さまざまに探求されてきた，その大きな理由に， IPMN は発育が遅く, 浸潤傾向が小さいため経過

*山形大学医学部器官機能統御学講座消化器 - 一般外 科学分野 (第一外科)

<受理日：平成 20 年 4 月 10 日 $>$
観察が可能なものが存在し, また膵の機能温存手 術を考慮するのに絶好の病変であったことが挙げ られる。

\section{膵管内乳頭粘液性腫瘍（intraductal \\ papillary mucinous neoplasm of \\ the pancreas : IPMN) の手術適応と手術}

主膵管型 IPMN は約 $80 \%$ が悪性なので, 主膵 管型と診断がつき次第手術適応となる. 分枝型 IPMN (Fig. 1) では壁在結節のあるものや, 径が $3 \mathrm{~cm}$ を超えるものが手術の適応となる ${ }^{2)}$ (Fig. 2). 分枝型の約 $20 \%$ が悪性であり，また約 $60 \%$ が経 過観察の対象となる. 通常型膵癌に比較して良好 な予後が得られる. 手術例の 5 年生存率は $78 \%$ で ある. しかし, 他藏器に浸潤したものや穿破した ものの予後はわるい ${ }^{3)}$.

手術術式には, 定型的な膵頭十二指腸切除術, 幽門輪温存膵頭十二指腸切除術や膵体尾部脾切除 術以外に, 膵分節切除術, 膵鈎部切除術, 膵頭十 


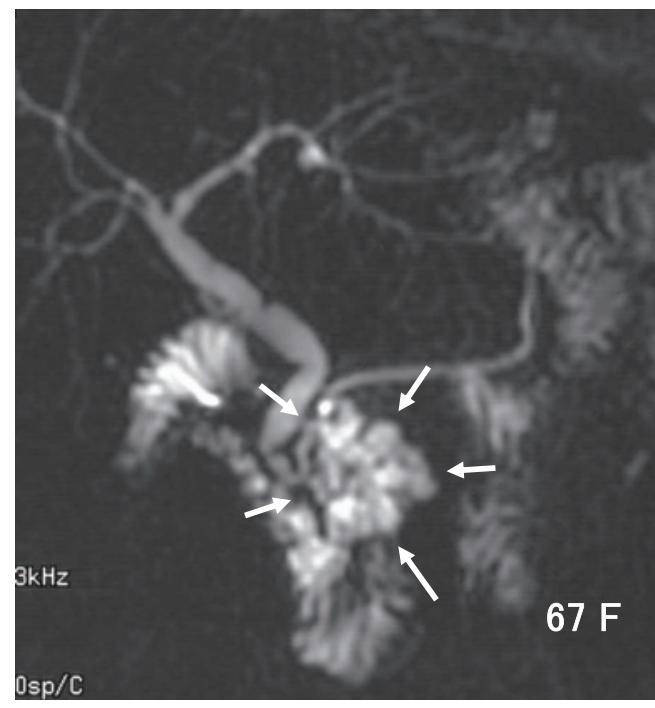

Fig. 1 IPMN 分枝型. 超音波内視鏡を含む画像診断 で隆起性病変は認められなかったが，切除標 本の病理組織学的検索では in situ carcinoma が認められた。

二指腸第二部切除術, 十二指腸温存膵頭十二指腸 切除術, 脾動静脈を温存した脾温存膵体尾部切除 術などがある。しかし，通常の手術で完治を期待 できる IPMN に対して, 安易に機能温存手術を選 択することは避けるべきであり，縮小手術の適応 は非常に厳密にするべきである，膵管内乳頭粘液 性腫瘍 (IPMN) に対してどのような術式を選択す るかということは難しい問題である。その理由と しては，いまだに IPMN の病態が十分に解明され ていないことが挙げられる。

\section{IPMN の病態の問題点}

われわれはこれまでIPMN の病態におけるさ まざまな問題点を報告してきだ).

(1)腫瘍・非腫瘍, 良悪性の病理学的な客観的基 準はありうるか.

(2) Hyperplasia $\rightarrow$ adenoma $\rightarrow$ carcinoma sequence は存在するか.

(3)良悪性の臨床診断は可能か.

(4)良性のものは経過観察でいいのか, どの程度 の malignant potential を有するのか ?

(5) in situ carcinoma はいつ浸潤するのか, つま

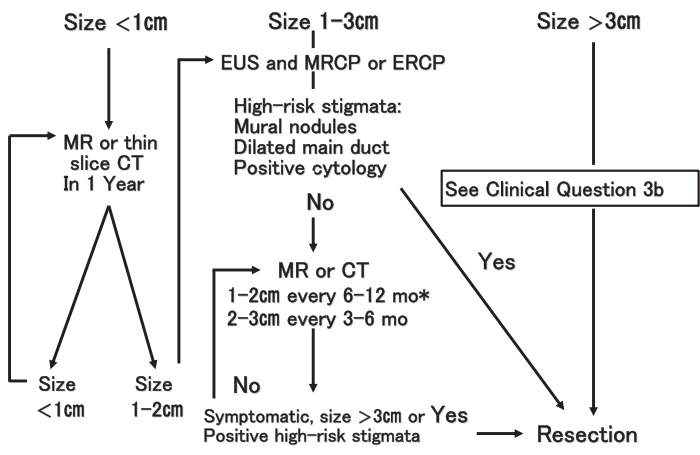

Clinical Question 3b

分枝型IPMNは全例を切除の適応とすべきか?

もしそうでないならば, 切除すべき症例と経過観察してよい

症例はどのように鑑別すればよいか?

ここで強調すべきことは, 治療方針はあくまでもここの 症例について考慮されるべきで, 患者の選択と検査反復に よる経過観察をよしとするかどうか, さらに安全に膵切除 を行う外科医がいるかどうかによって決定されるべきこと である。さらに, 30mm以上の分枝型IPMNをすべてすぐに 切除すべきかどうかを決定するには, この大きさで主膵管拡 張も壁在結節もない例の切除後病理検索によるデータを 蓄積する必要がある。

Fig. 2 IPMN/MCN 国際ガイドラインによる分枝型 IPMN の治療方針（文献 2 から引用・改変）

りどの程度の期間 in situにとどまっているのか.

(6)浸潤はどの程度になったら画像診断, その他 でとらえられるか. 微小浸潤は画像診断でとらえ られるか.

(7)浸潤し始めてからも slow growing か.

8浸潤してから，あるいは浸潤が明らかになっ てからの手術で間に合うか.

(9)さまざまな進展度の病変に対して, どのよう な手術がもっとも優れているか.

(10)どのような縮小手術が可能か.

以上の問題点ですでに明確な解決がついたもの はなく, 以下のようにさらに新たな問題も付け加 わっている。

(11)膵内多発・残膵再発の問題 : IPMN に関する 問題点としては，さらに膵内多発の問題および残 脺における再発が挙げられる。

(12)通常型膵癌の合併：IPMN の発生した膵は通 


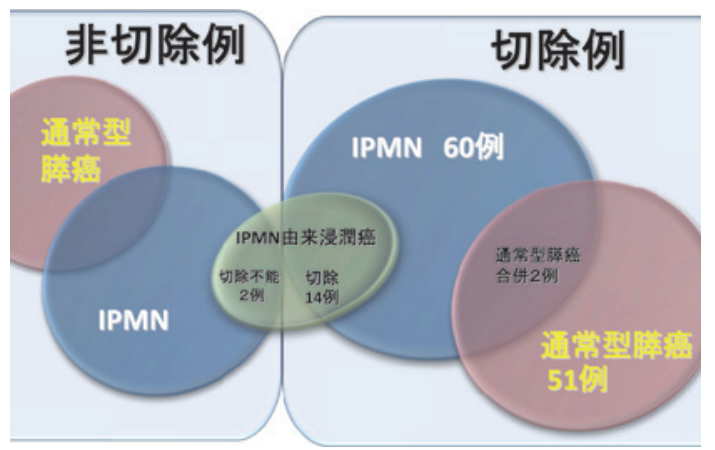

Fig. 3 IPMN, 通常型膵癌, 通常型膵癌を合併した IP$\mathrm{MN}$, IPMN 由来浸潤癌の切除例と非切除例の頻 度（山形大学消化器 - 一般外科, 1999-2007)

\section{Overall survival curve of the patients with IPMN}

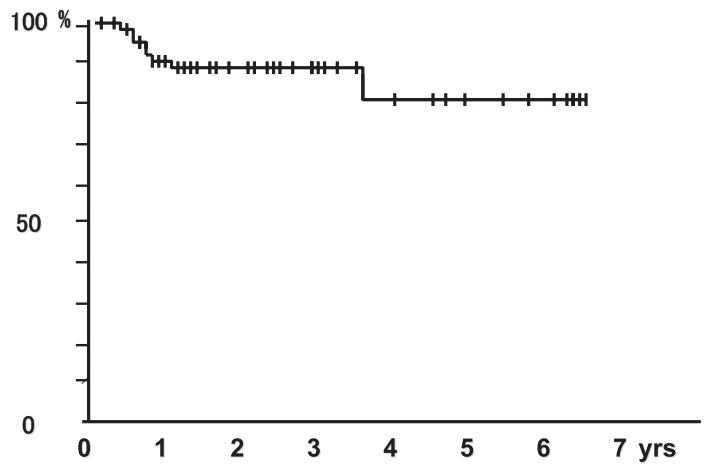

Fig. 4 IPMN 自検60例の術後生存曲線 (Kaplan-Meier 法)

常型膵癌の発生母地としても重要であるというこ とである. その頻度として約 $10 \%$ と報告されてい $ろ^{5.6)}$.

\section{手術適応をめぐって一IPMN は浸潤 し始めてからも slow growing か? -}

われわれの経験では, IPMN 切除症例 60 例のう ち 14 例が IPMN 由来浸潤癌である (Fig. 3)。う ち, 7 例は手術後に再発死亡している. 通常型膵癌 の術後 5 年生存率約 $10 \%$ に比較して, IPMN の術 後成績は良好であり（Fig. 4)，また IPMN 由来浸 潤癌でも Kaplan-Meier 法で約 40\% とかなり良 好なのは間違いない (Fig. 5)。この結果は IPMN が浸潤し始めてからも臨床的に slow growing で あることを示唆する所見である。しかしそれでも

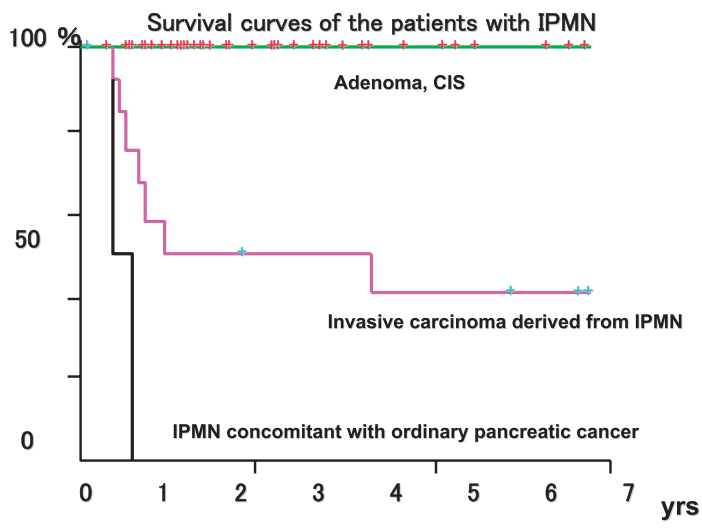

Fig. 5 IPMN 自検 60 例における腺腫・上皮内癌, IPMN 由来浸潤癌, および通常型膵癌合併例の術後生存 曲線（Kaplan-Meier 法）

IPMN 非浸潤癌の生存率約 100\% に比較すれば満 足すべき数字ではない.

IPMN 切除 60 例のうち 2 例には通常型膵癌が 合併している.これは IPMN からみると約 3\%, 同 時期に施行された通常型膵癌 51 例中約 $4 \%$ に相 当する.これら 2 例はいずれも術後 5 年生存せず に再発死している.

また，なんらかの理由によって経過観察をして 非手術となった症例で, 癌死した症例を 1 例, 経 過観察中に浸潤癌が確認され手術したがすでに肝 転移をきたしていて開腹・非切除に終わった症例 を 1 例それぞれ経験している (Fig. 3).

もちろん経過観察していてもほとんど変化しな い症例も多数ある. Yamaguchi $ら^{7)}$ は, 81 例の経 過観察中に外科に送った症例は 2 例であったと報 告している.

もっとも大切なことは, 浸潤を開始する直前か 開始した直後に経過観察から手術の方針とするべ きであり，浸潤の徴候となる所見をあきらかにし ていくことである. IPMN は少なくとも in situ carcinoma の段階で手術すれば直る病気である.

もちろん浸潤して宿主の命を奪うことのない症例 に対する不必要な手術は回避すべきであるが，手 遅れになってしまって癌死させてしまうのはもち ろんよくない。この点において, 外科医はきちん と手術をして直し, 患者を手術の合併症で失うこ とがないように, 細心の注意をはらわなくてはな 


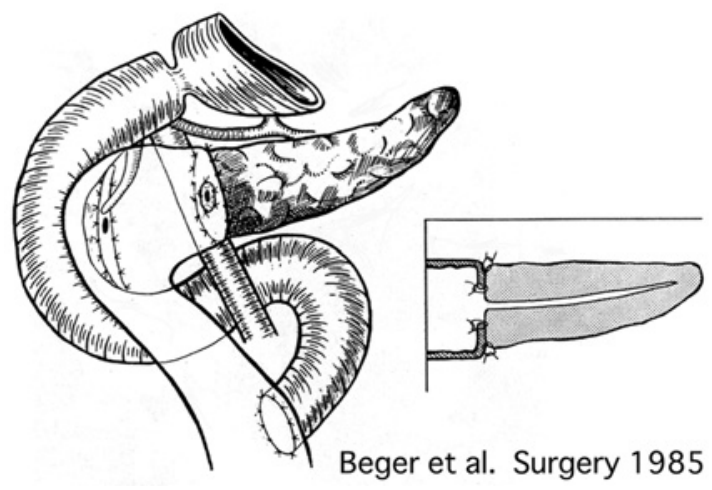

Fig. 6 Beger 法 ${ }^{9)}$

これは十二指腸に接する膵実質を十二指腸の主として第 二部, 第三部にわたり, 約 $1 \mathrm{~cm}$ 弱の幅で温存して, 膵頭 部を切除する.

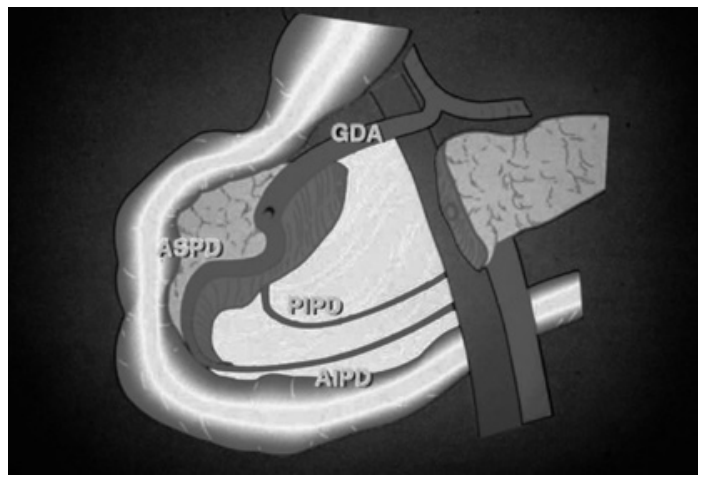

Fig. 7 十二指腸温存膵頭亜全摘術 $4,10 \sim 12)$ われわれが行った方法で Groove 領域の膵実質を残す方法 である. Treitzの癒合筋膜および萃頭部の動脈アーケイ ドを温存することによってこれらの血流が保持できる.

らない

\section{十二指腸温存膵頭切除術の隘路}

十二指腸温存膵頭切除術はとくに 1990 年代に IPMN に対する縮小手術の可能性として模索され 続けてきた. IPMN の手術適応の変化とともに, そ の術式には隘路が存在する。つまり上述した IPMN の問題と手術手技上の問題が大きく関係し ているのである8

十二指腸・胆管の温存を追求して膵実質の温存 部位を増やせば,「悪性の可能性があり, 一定以上 の広がりを有する手術適応症例に縮小手術の概念

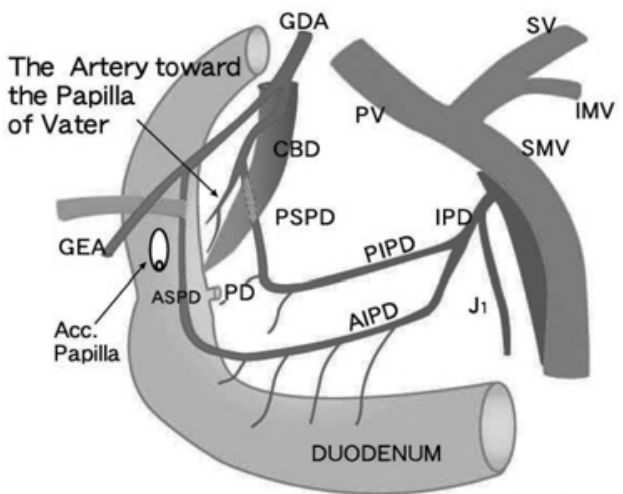

Kimura \& Nagai , Ann Surg 1995

Fig. 8 膵頭部の動脈解剖とVater 乳頭動脈 ${ }^{11)}$

を当てはめうるか」という問題に直面する．膵頭 部の膵実質をすべて切除すれば胆管, Vater 乳頭 部, 十二指腸の一部の温存ができなくなり, 温存 の内容は狭まる。

1. 十二指腸温存膵頭切除術

Beger 法 ${ }^{9)}$ (Fig. 6)

これは十二指腸に接する膵実質を十二指腸の主 として第二部，第三部にわたり，約 $1 \mathrm{~cm}$ 弱の幅で 温存して, 膵頭部を切除するということである. これはもっぱら慢性脺炎に対して行われてきた手 術である. 十二指腸第三部（水平脚）に接した脺 実質まで残す術式であるので，膵鈎部も一部残る ことになり，IPMN に対する手術としては適さな いと考えられる.

十二指腸温存膵頭亜全摘術 ${ }^{4,10 ~ 12)}$ (Fig. 7)

われわれが行った方法で Groove 領域の膵実質 を残す方法である. Treitzの癒合筋膜および膵頭 部の動脈アーケイドを温存することによってこれ らの血流が保持できる ${ }^{4,10,11)}$. とくに後上膵十二指 腸動脈から分岐して胆管下部右側を走行する Vater 乳頭動脈（Fig. 8) が温存されていることが 非常に重要で，十二指腸第二部および下部胆管の 血流を温存することが可能になる．外科解剖に基 づいた術式である．温存される臟器・機能も十二 指腸，胆管，Vater 乳頭部と十分である.

この方法では Groove 領域に残存させる膵実質 にIPMN が進展しているか, それが術前の臨床診 断でどこまで正しく検索できるか，という問題が 


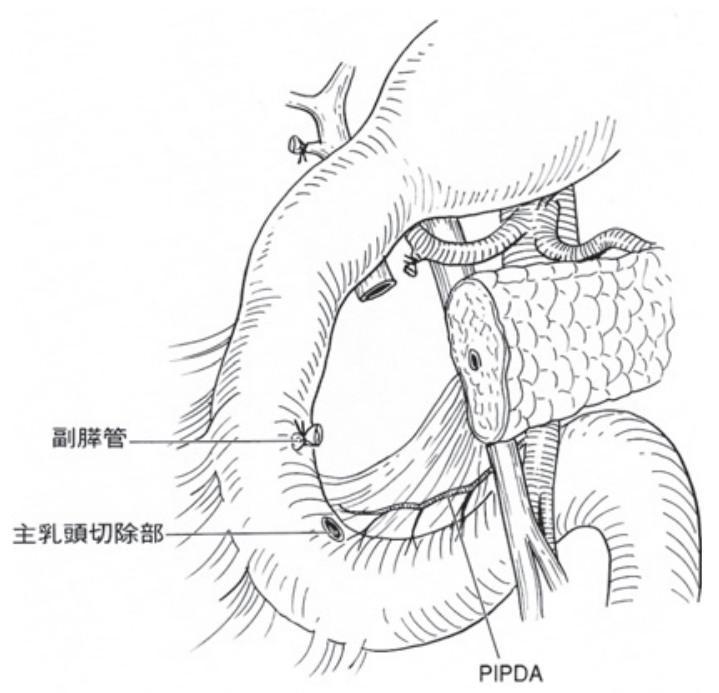

IMAIZUMI : TAN TO SUI 1990

Fig. 9 十二指腸温存膵頭全切除術 (今泉の方法) 13)

存在する. 膵下頭枝領域の分枝型 IPMN の手術適 応も以前よりは厳しくなり, 最大径 $3 \mathrm{~cm}$ 以上また は結節隆起が存在するものと考えられているこ と, 良性例はできるだけ避け, 悪性例のみを切除 したいという意識が臨床家の中にあること, 分枝 型 IPMN で最大径 $3 \mathrm{~cm}$ 以上でも経過観察があり うるという考え方も根強く存在することなどか ら，手術はより大きく悪性化した IPMN に限られ ていく傾向にある.このことから, IPMN の脺管内 の進展もより広くなっている可能性が考えられ る.

この術式は Groove 領域の分枝膵管に IPMN が 進展していないことを十分に確認してから行うべ き術式である。

今泉の方法 ${ }^{13)}$ (Fig. 9)

膵頭部の膵実質をすべて切除する点で上記の 2 つの方法とは異なる. 胆管下部は切除しているが, これは膵頭部の膵実質をすべて切除するため, 下 部胆管の血流として重要なVater 乳頭動脈や胆 管周囲の長軸に沿った動脈ネットワーク (epicholedochal plexus) の温存および perichoredochal が難しいためとわれわれは考えている。ま た十二指腸第二部の血流温存のためにKocherの 授動術を施行しないことが特徴である. 胆囊は切

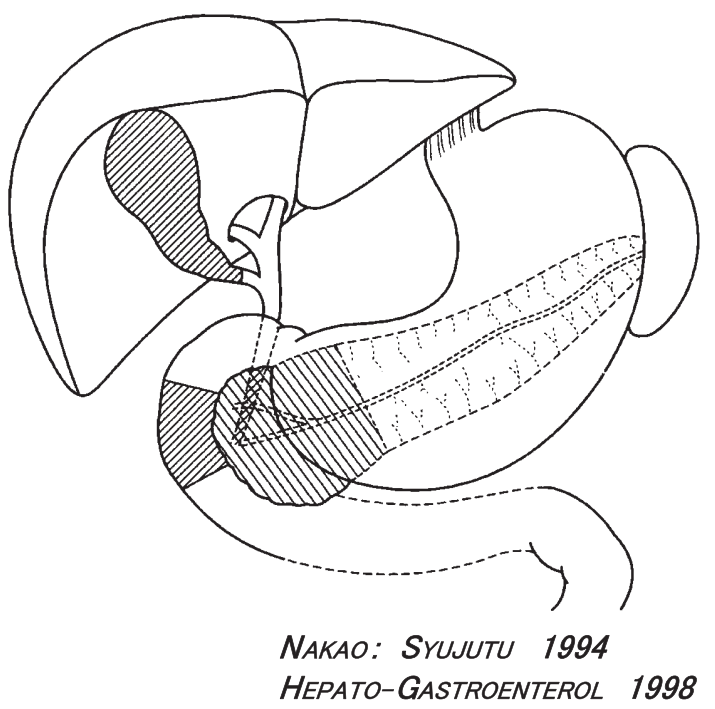

Fig. 10 膵頭十二指腸第二部切除術（中尾の方法） 14,15) 膵頭部の膵実質すべてと胆管下部, 十二指腸第二部, 胆囊 を切除する方法である.

除される.中部胆管は十二指腸に吻合する.

2. 膵頭十二指腸第二部切除術 (中尾の方法) ${ }^{14,15)}$ (Fig. 10)

膵頭部の膵実質すべてと胆管下部，十二指腸第 二部，胆囊を切除する方法である．脺頭部実質を すべて切除することで, Vater 乳頭動脈が犠牲に されることから，下部胆管と十二指腸第二部に血 流が不足するため, この部を切除するという点で, 血流理論的には正しいと考えられる.

すでに確立された術式である幽門輪温存膵頭十 二指腸切除術 (PpPD) と比較した場合, 残存十二 指腸の長さだけが異なるが, この術式の利点がど れだけ大きいかということが問題となる。

\section{十二指腸温存膵頭切除術における課題}

IPMN に対する十二指腸温存膵頭切除術にはさ まざまな問題が存在するが, それは IPMN の良悪 性, 膵管内進展あるいは微小浸潤の診断は可能か, などの臨床水準と深くかかわっている. 分枝型 IPMN の手術適応のコンセンサスが次第に得られ てきていることや，手術手技の問題も大きく関係 している. 十二指腸 - 胆管 $\cdot V$ ater 乳頭部の温存 を追求して膵実質の温存部位を増やせば,「悪性の 
可能性があり，一定以上の広がりを有する手術適 応症例に縮小手術の概念を当てはめうるか」とい う問題に直面する．膵頭部の膵実質をすべて切除 すれば胆管, Vater 乳頭部, 十二指腸の一部の温存 ができにくくなり，温存の内容は狭まる，十二指 腸温存膵頭切除術の今後の発展にとって重要なこ とは「縮小手術をしたことによって宿主 (患者)を 失ってはならない」という腫瘍外科手術の大前提 を念頭に置きながら，機能温存によっていかなる 恩恵を受けたかを客観的に示していくことであ る.

今後の十二指腸温存膵頭切除術の課題として は, IPMN の病態・診断に関する未解決の問題を 明らかにしていくべきであることはいうまでもな い. さらに技術的な問題点の解決はもとより, 機 能温存によっていかなる利点・恩恵を受けたかを 客観的に示していく必要がある.

手術適応にあたっては, 常に機能温存のリスク とベネフィットを十分に考え, 分析したうえで, 施行するべきである.

\section{脾臓温存尾側膵切除術}

脾動静脈および脾臓を温存した膵体尾部切除 術 $^{16 \sim 18)}$ は着実なひろがりをみせている．膵腫瘍や 慢性膵炎に対して世界で初めてわれわれが報告し た。脾動静脈を温存するため, 脾への血流が確実 に保たれる非常に安全な術式である。この手術は すこし手間がかかるものの手技的に難しい操作は なく，だれでも安全に行うことができる，慢性膵 炎やIPMN に対して適応を選んで広く行われる ようになってきている.

最近ではわれわれは HALS (Hand assisted laparoscopic surgery）を用いて膵体尾部・脾を脱 転させた後, 腹壁外で脾動静脈と膵実質との遊離 を行うことにより,さらに低侵襲の術式を心がけ ている.

\section{機能温存手術のリスクとベネフィット}

縮小手術を行ったことによって腫瘍が再発し患 者を失うことがあるとすれば，それはどのくらい の頻度以下なら許されると考えられるか?

\section{1. 早期胃癌}

早期胃癌に対する EMR の適応などとも考え合 わせて考えるべきである. すなわち, EMR 後にそ れによって患者を失うことはあってはならない し,あったとしても 1000 例のうち数人以内に留ま るべきであるという熟練外科医の意見がある.

\section{2. 大腸癌の局所切除}

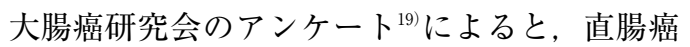
の局所切除の現況として直腸癌手術 11804 例 (85\%), 局所切除 1014 例 (7.3\%), 内視鏡切除 1088 例 (7.8\%) で, 局所切除術施行したのは Rb 81\%, Ra 19\% であり, 再発を $6.0 \%$ に認めている. 再発 様式は局所再発が $3.7 \%$, 肺転移が $1.5 \%$, 肝転移が $0.5 \%$ で 5 年生存率は $97.3 \%$ であるとし, 満足で きる結果であったと結論している。これからみる と, 局所切除を受けて肚門が残ることにより， $2.7 \%$ の命が奪われるのは許容範囲と医師および 患者が考えていると考えられる，人工肛門にする か, 肚門括約筋が残るかというのはその後の生活 の質 (quality of life：QOL)では非常に大切なこと である.この点, 肛門を残すか残さないか，とい うことの違いは，医師にとっても患者にとっても 目に見えて比較しやすい.

\section{3. 乳癌における乳房温存手術}

乳癌ではさまざまな要素が加わり一概にはいい にくいが, 乳房切除術を施行した場合には, 縮小 手術, 乳房温存手術に比べて, 約 2〜3\% 程度多く の命が救われるではないかとされている。これも 乳房が残るか残らないかという違いはわかりやす w.

これに対し, IPMN 53 例のうち再発例が 12 例 で, うち 8 例が非浸潤癌, また 9 例は局所再発で, 断端に異型上皮を認めた場合の再発率が高いとい う報告がある ${ }^{20)}$ 。これは非浸潤癌でも切離断端に 腫瘍が残った場合には再発する可能性の高いこと を示しており, 膵の切離断端をできるだけ腫瘍陰 性にして IPMN を取りきるべきであるという指 針を示す結果として重要なデータである. 機能温 存・縮小手術に対する警告を鳴らすデータといっ ても過言ではないかもしれない. 手術における最 大の $\mathrm{QOL}$ は再発しないこと, 生きていることで あり，とくに IPMN では「縮小」の意味を十分に 
考えて適応を決定することが必要である.

\section{世界の報告と機能温存手術のこれから}

世界的にもわれわれと同様にIPMN に対する 縮小手術に疑義を唱えている論文が報告されてい る. フランスのグループは膵の分節切除の検討を 行っているが, IPMN に対する手術としては多中 心性発生, 表層拡大のため再発が約 $40 \%$ と高率な ためすすめられないと報告している ${ }^{21}$. Sohn らも 同様にIPMNの $1 ， 3 ， 5$ 年生存率がそれぞれ 82，67，57\% と思ったよりよくないと考えてい る22. IPMN は考えられているより悪性であるこ とを認識して治療にあたるべきである.

十二指腸温存膵頭切除術の今後の発展にとって 重要なことは IPMN の病態に関する未解決の問 題点を明らかにしていくこと, 解剖学的基礎研究 を積み重ね技術的な問題点を解決すること, 機能 温存によっていかなる恩恵を受けたかを客観的に 示していくことなどが必要となる. IPMN に対す る安易な機能温存・縮小手術は避けるべきであ る.

\section{文献}

1）大橋計彦, 村上義央, 丸山雅一, 他. 粘液産生膵癌の 4 例一特異な十二指腸乳頭所見を中心として一. Progress of Digestive Endoscopy 1982 ; $20: 348-51$.

2) Tanaka M, Chari S, Adsay V, et al. International consensus guidelines for management of intraductal papillary mucinous neoplasms of the pancreas. Pancreatology 2005; 6: 17-32.

3) Kimura W, Sasahira N, Yoshikawa $T$, Muto $T$, Makuuchi M. Duct-ectatic type of mucin producing tumor of the pancreas - New concept of pancreatic neoplasia. Hepatogastroenterol 1996; 43: 692-709.

4) Kimura W, Kuroda A, Makuuchi M. Problems in the diagonsis and treatment of a so-called mucin-producing tumor of the pancreas. Pancreas 1998; 16: 363-9.

5）山口幸二, 大内田次郎, 許斐裕之, 中野賢二, 永井英 司, 田中雅夫. 通常型膵癌と IPMT の同時. 異時性多 発の可能性. 胆と膵 $2002 ; 23: 229-32$.

6) Moriya $T$, Kimura $W$, Sakurai $F$, et al. Minute invasive ductal carcinoma of the redisual pancreas after distal pancreatectomy for intraducta papillary-mucinous tumor. Int J Gastrointestinal Cancer 2002; 31: 191-7.

7) Yamaguchi $T, B a b a T$, Ishihara $T$, et al. Long-term follow-up of intraductal papillary mucinous neoplasm of the pancreas with ultrasonography. Clin Gastroenterol Hepatol 2005; 3: 1136-43.

8) 木村 理. 膵管内乳頭粘液性腫瘍 (IPMT) の病態と治 療の問題点一十二指腸温存膵頭切除術の隘路一. 膵臓 $2003 ; 18: 175-9$.

9) Beger H, Krautzberger W, Bittner R, et al. Duodenum-preserving resection of the head of the pancreas in patients with severe chronic pancreatitis. Surgery 1984; 97: 467-73.

10) Kimura W, Makuuchi M, Kuroda A. Characteristics and treatment of mucin producing tumor of the pancreas. Hepato-Gastroenterology 1998; 45: 2001-8.

11) Kimura W, Nagai H. Study of surgical anatomy for duodenum-preserving resection of the head of the pancreas. Ann Surg 1995; 221: 359-63.

12) Kimura W. Surgical anatomy of the pancreas for limited resection. J Hepato-Biliary-Pancreatic Surgery 2000; 7: 473-9.

13）今泉俊秀, 羽生富士夫, 鈴木 衛, 他. 十二指腸温存 膵頭全切除術. 消外 $1991 ; 14: 475-88$.

14）中尾昭公, 井上総一郎, 梶川真樹, 他. 膵頭十二指腸 第 II 部切除術. 手術 $1994 ; 53: 33-8$.

15) Nakao A. Pancreatic head resection with segmental duodenectomy and preservation of the gastroduodenal artery. Hepato-Gastroenterology 1998; 45: 533-5.

16) Kimura W, Inoue $T$, Futakawa N, Shinkai H, Han I, Muto T. Spleen-preserving distal pancreatectomy with conservation of the splenic artery and vein. Surgery 1996; 120: 885-90.

17) Kimura W, Fuse A, Hirai I, et al. Spleen-preserving distal pancreatectomy with preservation of the splenic artery and vein for intraductal papillary-mucinous tumor (IPMT): Three interesting cases. HepatoGastroenterology 2003; 50: 2242-5.

18) Kimura W, Fuse A, Hirai I, Suto K. Spleen preserving distal pancreatectomy for Intraductal Papillary-Mucinous Tumor (IPMT). Hepato-Gastroenterology 2004; 51: 86-90.

19）第 63 回大腸癌研究会. 直腸癌の局所切除の現況：ア ンケート集計. 2005.

20）森田利奈, 他. 膵管内乳頭腫瘍再発例の検討. 日消外 会誌 $2003 ; 36: 1002$.

21) Sauvanet A, Partensky C, Sastre B, et al. Medial pancreatectomy: A multi-institutional retrospective study of 53 patients by the French pancreas club. Surgery 2002; 132: 836-43.

22) Sohn TA, Yeo CJ, Cameron CL, Iacobuzio-Donahue CA, Hruban RH, Lillemore KD. Intraductal papillarymucinous neoplasms of the pancreas: An increasing recognized clinicopathological entity. Ann Surg 2001; 234: 313-22. 


\title{
Recent surgical strategies for intraductal papillary mucinous neoplasm
}

\author{
Wataru KIMURA, Toshiyuki MORIYA, Toshihiro WATANABE, \\ Yukinori KAMIO, and Ichiro HIRAI*
}

Key words: IPMN, Limited operation, Duodenum-preserving pancreatic head resection, Spleen preserving distal pancreatectomy

There are various unanswered problems about the conditions of intraductal papillary mucinous neoplasm(IPMN). These are as follows: How can the degree of tumor spreading be determined clinically? Is this tumor slow-growing after infiltration? Can we cure patients with this disease after the tumor apparently infiltrates? Which surgical procedures are indicated for tumors with various degrees of spreading? What kinds of limited or organ-preserving operations are possible? These problems may correspond to the potential malignancy of invasive carcinoma derived from IPMN as compared to that of ordinary ductal carcinoma of the pancreas.

In our series, invasive carcinoma derived from IPMN was found in 14 out of 60 cases with IPMN, and the five-year survival after operation was about $40 \%$ by Kaplan-Meier analysis. These results may suggest that IPMN is slow-growing after infiltration. However, the results are not satisfactory when comparing the five year survival of $100 \%$ of cases with non-invasive IPMN. Therefore, greater care is needed for the patients with IPMN as there is more malignant potential than we had thought. There are various limited operations. However, limited operation for neoplasm entails the risk that the patients will die from recurrent disease. It is also important that we objectively show the benefits obtained by limited surgery. Indications for organ preserving, limited operation should be very strict.

\footnotetext{
* Department of Gastroenterological and General Surgery, Yamagata University School of Medicine (Yamagata)
} 